\title{
The environmental situation in the socio-cultural development of Karachay-Cherkessia
}

\author{
Andrey Lezhebokov ${ }^{1,}{ }^{*}$, Elena Sergodeewa ${ }^{1}$, Lejla Tekeeva $^{2}$, Elena Grishai, ${ }^{3}$ and Vladimir \\ Grishai $^{4}$ \\ ${ }^{1}$ North Caucasus Federal University, 1, Pushkin Str., Stavropol, 355017, Russia \\ ${ }^{2}$ Karachaevo-Cherkessky State University named after U.D. Aliev, 29, Lenin St, Karachaevsk, \\ 369200, Russia \\ ${ }^{3}$ Krasnodar University of the Ministry of Internal Affairs of Russia,Yaroslavskaya 128, \\ Krasnodar,350912,Russia \\ ${ }^{4}$ Essentuki Institute of management, business and lav, 2, Ermolova Str., Essentuki, 357601, Russia
}

\begin{abstract}
The article presents the results of a sociological study of the attitude of the Karachay-Cherkessia Republic population to the essential components of the ecological situation. The significance of the ecological factor of the region as the basis for socio-cultural development and modernization of the territory of the republic is determined. A literature review shows the importance of such studies in regions with an extreme environmental situation and in regions traditionally considered to be prosperous and even resort areas. For such territories, the nature and absence of air and water pollution are a possible growth point, an attractive factor for forming tourist complexes. The development of tourism infrastructure and a competent media campaign will attract investors' funds and create prerequisites for increasing tourist flows. Analysis of the survey results showed that the republic's population as a whole positively evaluates the environmental situation, which is an additional condition for the success of the modernization process in the region.
\end{abstract}

\section{Introduction}

The essential characteristic of modern society is the ability to ensure harmonious interaction with the environment. The formation of a responsible attitude to nature, the development and implementation of a strategy for the careful use of resources is acute in the development agenda of modern civilization. Recognition of the global scale of the ecological situation means the necessity to activate the corresponding behaviour of each person first of all on the local level. At the same time, regions have different natural conditions, differing degrees of industrial impact on the environment. Consequently, the environmental situation differs significantly both at the level of the countries of the world and within a state. Even the differences between urban and rural environments are pretty significant, which leads to peculiarities of interaction between man and nature $[1,2]$.

\footnotetext{
* Corresponding author: leghebokov@yandex.ru
} 
However, even considered prosperous territories are part of the global society, and a responsible attitude to nature for residents should also be the essential condition of life. The Karachay-Cherkessia Republic, located in the North Caucasus, is an example of such territory. Unique natural and climatic conditions have formed a particular ecological complex, which allows a large part of the area to have the status of a resort. It means that environmental protection should become a determining factor in developing this region, being an essential component of socio-cultural dynamics.

The need to obtain a reliable picture of the interaction between society and nature in this locality defines the study's relevance of the residents' assessment of the environmental situation in the territory of residence [3]. At the same time, we agree that only multidisciplinary and comprehensive research can give a complete picture $[4,5,6]$, including the use of new analytical procedures [7, 8], as well as the achievements of civil science [9]. At the same time, revealing the residents' opinion is the most crucial element of more extensive researches and shows the level of satisfaction with the ecological component.

Let us note that the level of satisfaction of the population with living conditions is, in turn, one of the criteria for assessing the socio-cultural development of the territory [10]. In this aspect, it is essential to study the socio-cultural dynamics of the region as part of a larger entity [11], which is in the process of modernization [12]. Thus, Karachay-Cherkessia, as part of the North Caucasus, has both general and specific problems in ensuring sustainable development, affecting the processes of ecological development of the territory, which actualizes the research.

\section{Materials and methods}

The study aims to obtain representative data, which will make it possible to determine the perceptions of the inhabitants of the Karachay-Cherkessia Republic about the ecological state of the environment. In order to achieve this goal, we have to carry out the following set of tasks. Firstly, to determine the respondents' opinion about the quality of primary natural resources such as water and air. Secondly, to identify the residents' attitude towards the environment in their places of residence as an attractive factor. Thirdly, to analyze the possibility of transforming the environmental situation in the region into a point of growth and modernization of the socio-cultural sphere.

The theoretical and methodological basis of the work was the anthroposocietal approach as a socio-cultural direction of research into the peculiarities of the development of Russian regions. The methodology of empirical research is based on several procedures aimed at obtaining a relevant picture of the region's socio-cultural development with the subsequent analysis of the components of interest. The most important for our study is a sociological survey of the population and the subsequent analysis of the subjective picture of the ecological state of the region.

The survey of respondents is conducted under the supervision of Professor E.A. Sergodeeva by personal interview in the Karachay-Cherkessia Republic at the place of residence of respondents according to the Standard Methodology of the All-Russian Program "Socio-Cultural Evolution of Russia and its Regions" in March, June-October 2020, which resulted in the survey of 1000 people. The sample is stratified, quota-route. Therefore, the sampling error does not exceed 3\%. The data were processed and analyzed using the SPSS 18.0 package. 


\section{Results and discussion}

The results of the survey show that environmental problems, according to the respondents, exist in the Republic but have a specific colouring. The answers to the question about the quality of air and water evidenced this. So, to the question "Do you breathe clean air?" the following answers were received, presented in Figure 1.

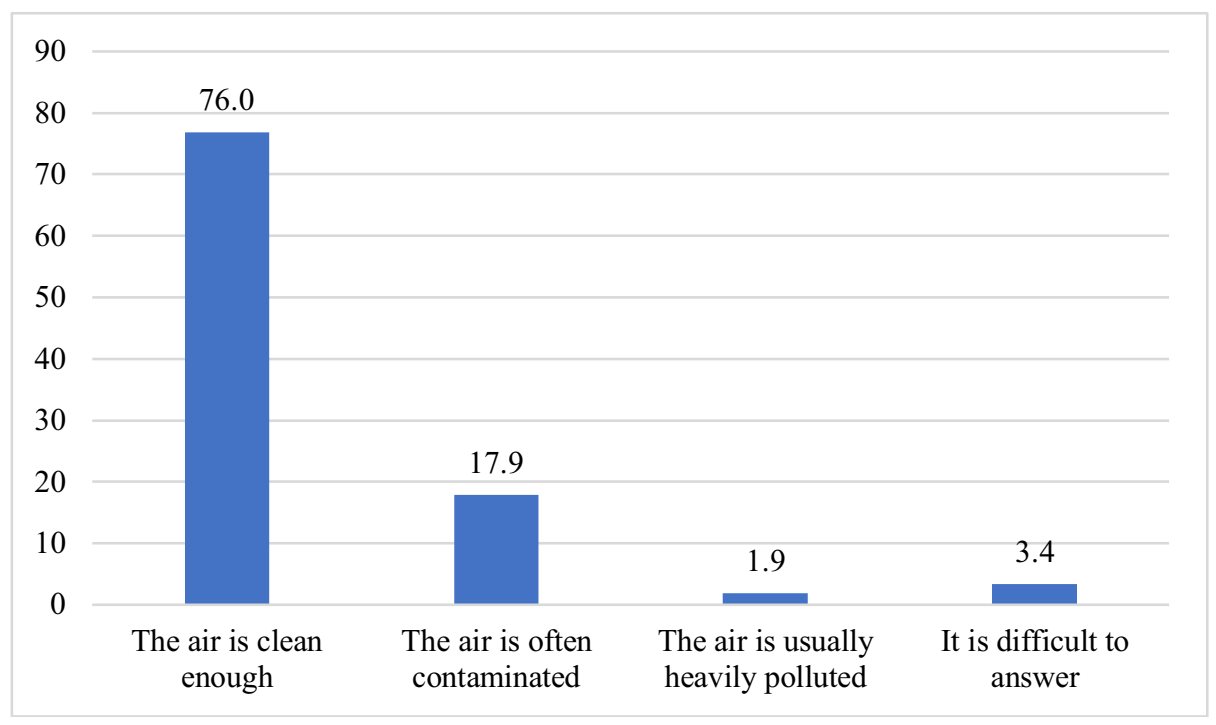

Fig. 1. Distribution of responses to the question about clean air in the Karachay-Cherkessia Republic, $(\%)$.

As we can see, $76.9 \%$ of the respondents are confident that the air is clean, which is relatively high. Almost $80 \%$ of the republic's territory is located in mountainous areas, some of which are specially protected natural areas, such as the Teberda Nature Reserve. Six recreational mountain zones are oriented to the reception and service of tourists. With a total population of 465 thousand citizens, more than 930 thousand people visited KarachayCherkessia for tourist purposes in 2020 [13]. Most tourists are focused on recreation in the mountains, as there is no industrial production as such. Thus, the cleanliness of the air noted by the respondents is an objective factor.

The analysis of the distribution of answers to the question about air purity between respondents living in urban and rural areas shows no significant difference between the answers of rural and urban residents, which is visible in Table 1.

Table 1. Distribution of answers to the question about clean air among residents of rural and urban areas $(\%)$.

\begin{tabular}{|c|c|c|c|c|c|}
\hline & $\begin{array}{c}\text { The air is } \\
\text { clean } \\
\text { enough }\end{array}$ & $\begin{array}{c}\text { The air is } \\
\text { often } \\
\text { contaminated }\end{array}$ & $\begin{array}{c}\text { The air is usually } \\
\text { heavily polluted }\end{array}$ & $\begin{array}{c}\text { It is difficult } \\
\text { to answer }\end{array}$ & Total \\
\hline Urban & 75.2 & 18.7 & 1.9 & 4.2 & 100 \\
\hline Rural & 78.4 & 17.4 & 1.9 & 2.3 & 100 \\
\hline
\end{tabular}

The lack of a significant difference can be considered the peculiarities of the settlement of the Republic's inhabitants and the lack of extensive production facilities in the cities. Indeed, economic reforms have led to a decrease in the industrial performance of the Republic. In addition, at the time of the survey, there was a special regime associated with the spread of new coronavirus infection. 
The most important environmental factor is the availability and quality of drinking water. When analyzing the answers to the question about the purity of consumed water, the following picture was obtained in Figure 2.

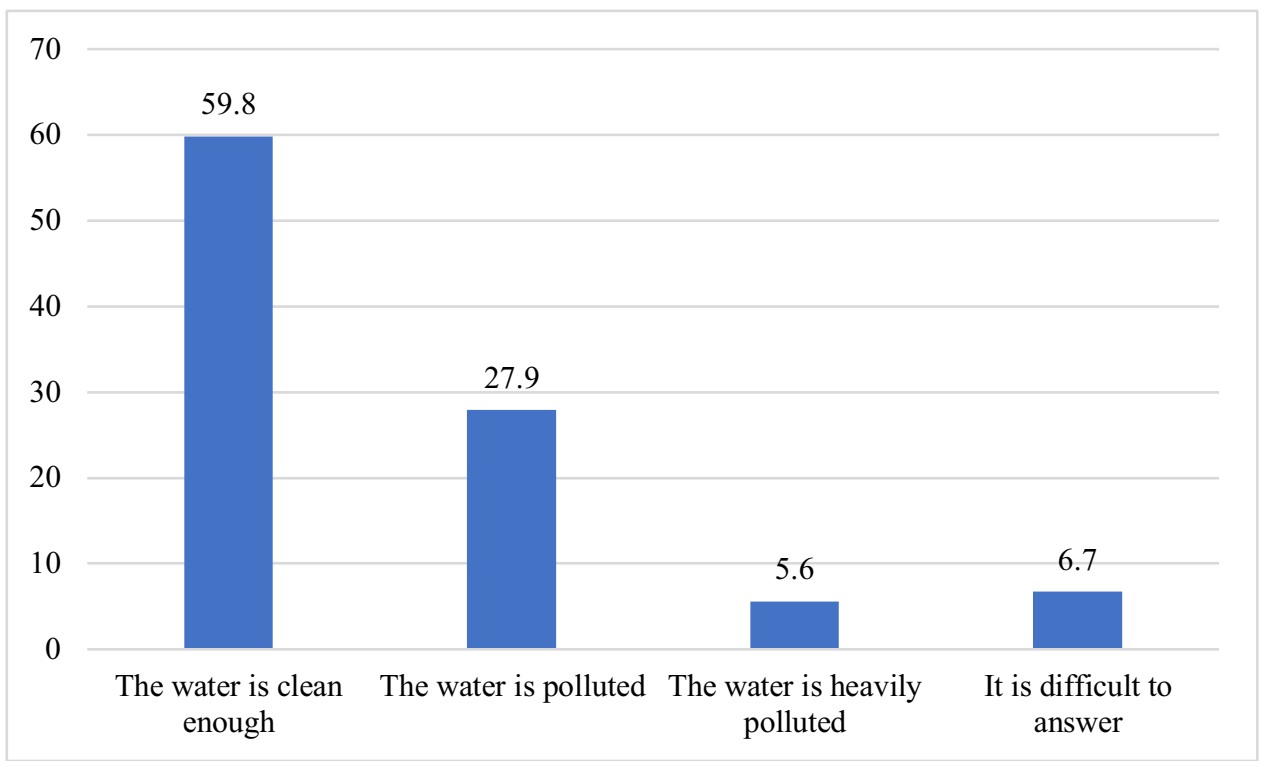

Fig. 2. Distribution of responses to the question about water purity in the Karachay-Cherkessia Republic, (\%).

As we can see, only $59.8 \%$ of respondents consider the water they drink clean. This result is entirely unexpected at first sight because there are many water bodies and rivers on the Republic territory. Currently, there are up to 130 mountain lakes and about 180 rivers. In addition, there is a system of the Big Stavropol Canal, which supplies drinking water for the Stavropol Territory. However, the water that the population uses for drinking and cooking is most often supplied to the water supply system after treatment, including the use of chemical reagents, which may reduce its quality in the eyes of the population. In addition, as shown by studies [14], the water in some water bodies is contaminated due to the work of building materials companies, inefficient operation of landfills, the presence of unauthorized dumps. Table 2 makes it possible to say that this situation is characteristic equally between urban and rural residents.

Table 2. Distribution of answers to the question about water purity among residents of rural and urban areas $(\%)$.

\begin{tabular}{|c|l|l|l|l|l|}
\hline & $\begin{array}{l}\text { The water is } \\
\text { clean enough }\end{array}$ & $\begin{array}{c}\text { The water is } \\
\text { polluted }\end{array}$ & $\begin{array}{c}\text { The water } \\
\text { is heavily } \\
\text { polluted }\end{array}$ & $\begin{array}{c}\text { It is difficult to } \\
\text { answer }\end{array}$ & Total \\
\hline Urban & 59.1 & 26.5 & 6.5 & 7.9 & 100 \\
\hline Rural & 60.4 & 29.2 & 4.7 & 5.7 & 100 \\
\hline
\end{tabular}

Thus, the respondents express pretty good air and satisfactory water conditions in the Karachay-Cherkessia Republic. However, it is also essential to present the general idea of the residents about the surrounding nature. According to the survey, $57.7 \%$ of respondents consider beautiful nature as an attractive feature of the region. It is indicative that among this cohort of respondents, $43.7 \%$ are men, and $56.3 \%$ are women. There are also age differences in the answers, clearly visible from the data presented in Table 3. 
Table 3. Distribution of responses to the question beautiful nature as an attractive feature of the region $(\%)$.

\begin{tabular}{|c|c|c|c|c|c|}
\hline Respondent's age & $\mathbf{1 4 - 2 4}$ & $\mathbf{2 5 - 3 5}$ & $\mathbf{3 6 - 4 9}$ & $\mathbf{5 0 - 7 1}$ & Total \\
\hline $\begin{array}{c}\text { Beautiful nature } \\
\text { is an attractive } \\
\text { feature of the } \\
\text { region }\end{array}$ & 39.1 & 22.5 & 23.1 & 15.3 & 100.0 \\
\hline
\end{tabular}

No significant differences were found between the answers of respondents living in rural and urban areas.

It should be noted that among the unattractive features of the region, "too harsh climate" was indicated only by $4.6 \%$ of respondents, while there is an inverse picture between the answers of men $(56.2 \%)$ and women $(43.8 \%)$ to this question, compared to the previous question. At the same time, residents of rural areas $(63.0 \%)$ more often point out the excessive severity of the climate than urban residents $(37 \%)$. In the latter case, such a distribution is caused, apparently, by the peculiarities of the population's economic life.

In general, good natural-climatic conditions due to the geographical environment and the preserved prosperous ecology make the republic a promising target for modernization changes. Therefore, the socio-cultural development of the region depends entirely on infrastructural changes, which in the future, as experience shows [15, 16, 17], can significantly change the situation even in depressed areas.

\section{Conclusion}

The Karachay-Cherkessia Republic, as part of the North Caucasus economic region, has undoubted advantages in the state of the natural environment. The reasons for this circumstance lie in the peculiarities of the geographical environment of the region and the complexity of socio-economic development, focused primarily on the agrarian sphere. Industrial facilities located on the republic's territory are in crisis times and are not significant factors of environmental pollution.

Orientation on development of tourism industry, especially clearly shown recently, has all chances to form several recreation centres in the republic. The economic stimulation of tourism and the preservation of the unique ecological component contribute to this. In order to fulfill this task, it is necessary to maintain the status of an ecologically clean region and, first of all - among the local population [18].

Currently, the population considers insufficient quality drinking water to be the leading environmental problem. Given the vast natural reserves of water on the territory of Karachay-Cherkessia, perhaps the reasons for this opinion lie in the treatment system in need of modernization. However, in general, the population considers the environmental condition of the territory to be entirely satisfactory, which in the future will allow the formation of sustainable complexes of socio-cultural modernization.

\section{Acknowledgments}

The research was funded by RFBR, project number 20-011-00260 «Perspectives of Sociocultural Development of the Karachay-Cherkessia Republic»

\section{References}

1. R.Y.R. Oh, K.S. Fielding, T.P.L. Nghiem et al., People Nat. 3, 405-417 (2021) https://doi.org/10.1002/pan3.10181 
2. M. Soga, K.J. Gaston, Frontiers in Ecology and the Environment 14(2), 94-101 (2016) https://doi.org/10.1002/fee.1225

3. C. Bieling, T. Plieninger, H. Pirker, C.R. Vogl, Ecol. Econ. 105, 19-30 (2014) http://dx.doi.org/10.1016/j.ecolecon.2014.05.013

4. S. Jacobs, N. Dendoncker, B. Martín-López, et al., Ecosystem Services 22, 213-220 (2016) https://doi.org/10.1016/j.ecoser.2016.11.007

5. V.A. Ivashova, V.A. Burlyaeva, I.V. Yushchenko et al., E3S Web of Conferences 224, 04039 (2020)

6. V. Rodionova, L. Shvatchkina, G. Mogilevskaya et al., E3S Web of Conferences 210, 14005 (2020)

7. S. Kelling, W.M. Hochachka, D. Fink et al., BioScience 59, 613-20 (2009) DOI: 10.1525/bio.2009.59.7.12

8. S.E. Hampton, C.A. Strasser, J.J. Tewksbury et al., Front Ecol Environ 11, 156-62 (2013) DOI: 10.1890/120103

9. C.C. Conrad, K.G. Hilchey, Environ. Monit. Assess. 176, 273-91 (2011) DOI: $10.1007 / \mathrm{s} 10661-010-1582-5$

10. N.I. Lapin, Socis. 3, 3-14 (2018)

11. P.A. Sorokin, Social and Cultural Dynamics (St. Petersburg, 2000)

12. N.I. Lapin, Socis. 1, 5-10 (2015)

13. Socio-economic situation of the North Caucasian Federal District in the first half of 2020 (M., 2020) https://rosstat.gov.ru/folder/11109/document/13260

14. N.S. Dega, F.H. Bostanova, A.R. Bairamkulova et al., Regional Environmental Issues 2, 59-64 (2019)

15. M. Mayor, R. Ramos, Sustainability (Switzerland) 12(11), $4693 \quad$ (2020) https://doi.org/10.3390/su12114693

16. L. Camarero, J. Oliva, Palgrave Communications 5(1), 95 (2019) DOI: 10.1057/s41599019-0306-X

17. J. Hite, Agricultural and Applied Economics Association 19(2), 230-240 (1997)

18. L. Filimonyuk, Y. Lobeyko, V. Ivashova et al., E3S Web of Conferences 203, 05021 (2020) 